\title{
Ascending aorta dilatation common feature which correlate with left ventricular hypertrophy in fabry disease
}

\author{
Mourad Bensalah ${ }^{1 *}$, Ferreira Antonio ${ }^{1}$, Cedric Collin ${ }^{1}$, Pierre Boutouyrie ${ }^{1}$, Dominique Germain ${ }^{2}$, Elie Mousseaux \\ From 2011 SCMR/Euro CMR Joint Scientific Sessions \\ Nice, France. 3-6 February 2011
}

\section{Purpose}

To describe the prevalence and characteristics of aortic root dilatation in male patients with Fabry disease (FD) and to assess its relationships with left ventricular remodelling.

\section{Methods and results}

Fourty-four adult males with FD (age: $38.1 \pm 11$. 3 years) and 44 healthy male controls matched for age were included. The diameters of the ascending and descending aorta were measured by magnetic resonance imaging (MRI) at the level of the sinuses of Valsalva, sinotubular jonction, tubular portion, aortic arch and descending aorta. Cardiac geometry and properties were also assessed by MRI.

Dilatation of the ascending aorta was found in $40.9 \%$ of the patients with FD and was predominantly located at the sinuses of Valsalva $(38.2 \pm 4.6$ vs. 32.4 $\pm 3.1 \mathrm{~mm}, P<0.0001)$. The dilatation was associated with increased left ventricular mass (LVM), independently of age and presence of hypertension. In multivariate analysis, LVM was the main determinant of the sinus diameter $\left(R^{2}=13.6 \%, P<0.05\right)$. When assessing the regional remodelling of the ascending aorta by a mean diameter estimated at three different levels, both LVM $\left(\mathrm{R}^{2}=30.4 \%, P=0.0001\right)$ and renal failure $\left(\mathrm{R}^{2}=7.3 \%, P=0.0297\right)$ were independently associated with aortic dilatation.

\section{Conclusion}

Dilatation of the ascending aorta is a common finding in male patients with FD, witch correlate with left

${ }^{1}$ Hospital Georges Pompidou, Paris, France

Full list of author information is available at the end of the article ventricular hypertrophy. This further expands the phenotype expression of Fabry disease.

Author details

${ }^{1}$ Hospital Georges Pompidou, Paris, France. ${ }^{2}$ Hospital Raymond Poincare Garches, Paris, France.

Published: 2 February 2011

doi:10.1186/1532-429X-13-S1-P307

Cite this article as: Bensalah et al:: Ascending aorta dilatation common feature which correlate with left ventricular hypertrophy in fabry disease. Journal of Cardiovascular Magnetic Resonance 2011 13(Suppl 1): P307.

Submit your next manuscript to BioMed Central and take full advantage of:

- Convenient online submission

- Thorough peer review

- No space constraints or color figure charges

- Immediate publication on acceptance

- Inclusion in PubMed, CAS, Scopus and Google Scholar

- Research which is freely available for redistribution 